\title{
Mechanisms of Investigation Criminal Planning Involving Children as Performer
}

\section{Andrian Subarjo ${ }^{*}$ and Umar Ma'ruf*)}

*) Master of Law, Faculty of Law, Universitas Islam Sultan Agung Semarang, Indonesia, E-mail: andriansubarjo2@gmail.com

${ }^{* *}$ ) Master of Law, Faculty of Law, Universitas Islam Sultan Agung

\begin{abstract}
.
The objectives of this research are as follows: To identify and analyze the process of resolving the crime of premeditated murder which involves a child as the perpetrator. To find out and analyze legal considerations by the police in law enforcement against the crime of accidental murder involving a child as the perpetrator. The research method used is research that combines juridical and empirical. Based on the results of this study, the process of resolving premeditated murder involving children as perpetrators is required for the settlement of cases of juvenile crime as regulated in Article 7 paragraph (1) of Act No. 11 of 2012 concerning the Juvenile Criminal Justice System.

Keywords: Investigation; Crime; Planned Murder; Children.
\end{abstract}

\section{Introduction}

Article 1 Paragraph (3) of the 1945 Constitution of the Republic of Indonesia (hereinafter abbreviated to the 1945 Constitution of the Republic of Indonesia) confirms that the Republic of Indonesia is a state based on law (rechtstaat). ${ }^{1}$ In Indonesia, in order to enforce the rule of law as we aspire to, efforts need to be made so that the public knows the ins and outs of the applicable law. Indeed, at present, in an effort to ensure the maintenance of solid national stability in order to support the implementation of development, the government has made various efforts but in reality there are still actions from members of the community that disturb security and public order, either directly or indirectly which will affect the pattern. Their life.

In order to achieve objectives in criminal justice, each legal officer (Police, Attorney, Judge), although their duties are different, they must work in a single system, meaning that the work of each legal officer must be functionally related. In this case, the criminal justice is viewed as a system, because in the criminal justice there are several institutions, each of which has the authority and duties in accordance with its field and applicable regulations. Although in criminal justice there are various components, the targets of all these institutions are overcoming crime (Over coming of crime) and prevention of crime (Prevention of crime). Therefore the criminal justice system must be built from social processes in society. ${ }^{2}$

\footnotetext{
${ }^{1}$ Waluyo, Bambang. (2004). Pidana Dan Pemidanaan. Jakarta: Sinar Grafika. p. 33.

${ }^{2}$ Adang, and Yesmil Anwar. (2009). Sistem Peradilan Pidana Konsep Komponen Dan Pelaksanaannya Dalam Penegakan Hukum Di Indonesia. Bandung: Widya Padjadjaran. p. 28.
} 
The National Police as an investigator in handling child crimes is required to diversify through a restorative justice approach. The problem of this research is using the analysis knife of restorative justice theory and discretion theory. The application of diversion by investigators as a form of settlement of child criminal cases through a restorative justice approach in general is in accordance with the provisions of Act No. 11 of 2012 concerning the Criminal Justice System for Children by way of deliberation by involving victims, children, the community in finding solutions to improve, reconciliation. , and reassuring that is not based on vengeance. The obstacles that investigators encountered in implementing diversion as a form of settlement of juvenile cases at the Central Java Regional Police came from the victim's family who wanted the case to be processed through the judiciary, the difficulty of being invited to hold diversion meetings and the existence of a mode of extortion against the perpetrator. Other obstacles are the limitations of Bapas officers and social workers and the failure to reach a diversion agreement. To overcome this obstacle, the education office approaches the victim's family, coordinates with Bapas and if there is no diversion agreement, the case will be transferred to the prosecutor's office. Other obstacles are the limitations of Bapas officers and social workers and the failure to reach a diversion agreement. To overcome this obstacle, the education staff approached the victim's family, coordinated with the Bapas and if there was no diversion agreement, the case was transferred to the prosecutor's office. Other obstacles are the limitations of Bapas officers and social workers and the failure to reach a diversion agreement. To overcome this obstacle, the education office approaches the victim's family, coordinates with Bapas and if there is no diversion agreement, the case will be transferred to the prosecutor's office. ${ }^{3}$

The objectives of this research are as follows: To identify and analyze the process of resolving the crime of premeditated murder which involves a child as the perpetrator. To find out and analyze the difference between the settlement of traffic accidents by children that cause death and adult offenders. To find out and analyze legal considerations by the police in law enforcement against the crime of accidental murder involving a child as the perpetrator.

\section{Research methods}

The research method used is research that combines juridical and empirical. The data source of this research comes from primary data and secondary data, the data is obtained by collecting documents on criminal cases.

\footnotetext{
${ }^{3}$ Umar Ma'ruf, and Anita Indah Setyaningrum. Diversi Sebagai Bentuk Penyelesaian Perkara Pidana Anak Melalui Pendekatan Restorative Justice Oleh Penyidik Polda Jawa Tengah, Jurnal Hukum Khaira Ummah Vol. 12. No. 4 December 2017, Unissula.
} 


\section{Results and Discussion}

\subsection{The process of resolving the crime of premeditated murder which involves a child as the perpetrator}

Law enforcement in Indonesian is known in several terms outside of law enforcement, such as law enforcement. But it seems that the term law enforcement is the most frequently used and thus in the future the term will be more established or become a term that is used. The law must be implemented and enforced, everyone hopes that the law can be enacted in the event of an event that occurs. How the law should apply. Basically, you should not deviate even though the world is collapsing, the law must be enforced. ${ }^{4}$

The efforts to resolve the diversion process in cases of premeditated murder involving children as perpetrators, as required for the settlement of cases of juvenile crime as regulated in Article 7 paragraph (1) of Act No. 11 of 2012 concerning the Juvenile Criminal Justice System. In this process, the researcher puts the theory of law enforcement / legal certainty, because the SPPA Law itself requires that the process be carried out. The solution taken by police investigators to solve criminal cases, especially those involving child offenders, is Diversion, in this case it is carried out as an effort to resolve criminal cases of premeditated murder by the police. This Diversion effort is carried out in a family manner so that children are not labeled as criminals and do not receive negative stigma from society.

The provisions of Diversion are specifically regulated in Article 6 to Article 16 of Act No. 11 of 2012, however the regulations in its implementation will be regulated in government regulations. The form of diversion as regulated in this provision is carried out through deliberations involving children and their parents / guardians, victims and / or their parents / guardians, social advisers and professional social workers, and may also involve Social Workers and / or the community.

The process of implementing diversion holds the principle of restorative justice / Restorative justice system by taking into account the interests of victims; children's welfare and responsibility; avoidance of negative stigma; avoidance of retaliation; harmony of society and propriety, morality, and public order. Investigators, public prosecutors and judges when considering whether to carry out diversion or not, must pay attention to: the category of criminal acts committed by children, the age of the child, the results of social research from BAPAS, material and non-material losses caused by children's behavior, how the level of attention and community opinion on the case, and support the family and community environment.

Restorative justice and mediation in Indonesia do not have a definite legal umbrella so that the rule of law has not regulated the implementation process, but the reality on the restorative field is that justice or mediation processes are commonplace and have a positive impact. In law enforcement, the priority is the

\footnotetext{
${ }^{4}$ https://knowledgeisfreee.blogspot.com/2015/10/pengertian-penegakan-hukum-kedasaran.html, downloaded on November 26, 2020 at 12:33 WIB.
} 
sense of justice for both the victim and the perpetrator so that it becomes the mediation between the very influential parties in the settlement. In the implementation of Restorative Justice and mediation, it can only be carried out against legal processes carried out by children as (minor) offenders with the term Diversion, but for other general crimes cases there are no rules governing them. ${ }^{5}$

Children who become perpetrators of criminal acts always increase, in certain cases, children who are perpetrators are of special concern to law enforcement officials. One solution that can be taken in handling cases of juvenile crime is the restorative juctice approach, which is carried out by way of diversion. Diversion is carried out to provide protection and rehabilitation to perpetrators in an effort to prevent children from becoming adult criminals. Diversion of child perpetrators of criminal acts is carried out by the three components of the criminal justice system in Indonesia, from the police, prosecutors to courts. ${ }^{6}$

The process of resolving the crime of premeditated murder which involves a child as the perpetrator is as required for the settlement of cases of juvenile crime as regulated in Article 7 paragraph (1) of Act No. 11 of 2012 concerning the Juvenile Criminal Justice System

\subsection{Legal considerations by the police in law enforcement against the crime of catastrophic murder involving a child as the perpetrator}

The crime of premeditated murder did not just happen, but for a reason. Because there is a cause it must be analyzed and found, so that corrective action to that cause can be carried out and with further preventive measures can be prevented. Murder especially in this case a premeditated murder is an act that is planned.

Children who commit delinquency that lead to crimes must be held accountable for their actions. Currently, the prevention and control of delinquency has resulted in minor crimes being committed through the implementation of the juvenile justice system using a restorative justice approach. The concept of restorative justice is a very important consideration in solving criminal cases committed by children. The Supreme Court has issued Supreme Court Regulation (Perma) No. 2 of 2012 concerning Adjustments to the Limits of Minor Crimes and the Amount of Sanctions in the Criminal Code, which essentially stipulates that the maximum loss limit in cases (minor crimes) is 2.5 million, and in cases of a maximum penalty of three months in prison or a fine, as well as in the provision of tips for settlement should promote Restorative Justice. Child settlement, which is directed to resolve informally or outside the court, by involving all parties involved in a criminal act that has occurred. Minor criminal offenses committed by children

\footnotetext{
${ }^{5}$ Akhmad Khisni, and Ragil Tri Wibowo. Restorative Justice in Application for Crime Investigation on Property, Jurnal Daulat Hukum Volume 1 No. 2 June 2018 ISSN: 2614-560X, Unissula.

${ }^{6}$ Ananda, Fiska. Penerapan Diversi Sebagai Upaya Perlindungan Hukum Terhadap Anak Pelaku Tindak Pidana, Jurnal Daulat Hukum Vol. 1. No. 1 March 2018 ISSN: 2614-560X, Unissula.
} 
under Act No. 11 of 2012 are committed through a diversion mechanism by means of mediation or deliberation. ${ }^{7}$

To get justice in the eyes of the law, assistance must be carried out without discrimination or status and other factors. According to Act No. 11 of 2012 concerning the Criminal Justice System for Children, the police as the first law and justice enforcement agency to handle this case, especially in handling cases of traffic accidents that cause death by child offenders. So that the police are obliged to explore, follow and understand the legal values that live in society, therefore the role and position of children is very exclusive and guaranteed by law. Correct consideration can provide the fairest possible decision on the criminal act in lawsuits and is also the most important thing that will have a major impact on the child. Therefore,

In accordance with Act No. 11 of 2012 concerning the Juvenile Criminal Justice System, a restorative justice approach is needed for the approach carried out by Diversi to be applied at every stage of the process. ${ }^{8}$

The regulatory component arises from a number of legal rules regarding the application of restorative justice in investigations that have been regulated in police regulations. ${ }^{9}$ The police prioritizes Restorative justice by settling criminal cases by involving perpetrators, victims, families of perpetrators / victims, and other related parties to jointly seek a fair solution by emphasizing restoration to its original state, and not retaliation.

Legal considerations in law enforcement against the crime of premeditated murder involving children as perpetrators is that law enforcement uses Diversionary settlement with many efforts made by several parties which are taken into consideration, including the child is 16 years 10 months old, while in school he has good behavior. , agreed to have amicable deliberations between the suspect, victim and witnesses, agreed to carry out the diversion and received a diversion decision from the court.

\section{Closing}

The process of resolving the crime of premeditated murder which involves a child as the perpetrator is as required for the settlement of cases of juvenile crime as regulated in Article 7 paragraph (1) of Act No. 11 of 2012 concerning the Juvenile Criminal Justice System. Legal considerations in law enforcement against the crime of premeditated murder involving children as perpetrators is that law enforcement uses Diversionary settlement with many efforts made by several parties which are taken into consideration, including the child is 16 years 10 months old, while in school he has good behavior, agreed to have amicable

\footnotetext{
${ }^{7}$ Sri Kusriyah, and Rizky Adiyanzah Wicaksono. Implementation Of Restorative Justice Approach In Legal Protection Against Lightweight Crime By The Children, Jurnal Daulat Hukum Volume 1 Issue 4 December 2018 ISSN: 2614-560X, Unissula.

${ }^{8}$ Maryanto, and Hadi Noor Cahyo. Implementation Of The Settlement Of The Case Restorative Justice In Fights By Children Because The Effect Of Liquor (Case Study In The Polres Kudus), Jurnal Daulat Hukum Volume 2 Issue 1, March 2019 ISSN: 2614-560X, Unissula.

9 Umar Ma'ruf, and Yudi Hendarto. Diversion In Children Criminal Justice System Through Restorative Justice, Jurnal Daulat Hukum Volume 1 Issue 2, June 2018 ISSN: 2614-560X, Unissula.
} 
deliberations between the suspect, victim and witnesses, agreed to carry out the diversion and received a diversion decision from the court.

Law enforcement officers, especially the police, as protectors, protectors and public servants, are at the forefront of law enforcement and the community, they are obliged to seek to resolve children's cases by means of diversion, although in the end the child perpetrators and victims will prefer other solutions; To parents of children as perpetrators of crimes, and community institutions such as BAPAS, community leaders and others who play an important role in assisting children as perpetrators of crimes, they should pay attention to the interests of the rights of these children. Children as criminals must be accompanied, so that they receive direction and guidance, so that their future will be better. With the implementation of this Diversion, the number of crimes committed by minors should be able to minimize; The local government should prioritize more concern for children who are either in school or as perpetrators of crimes, although children as criminals have the right to legal protection from the government, because children are the nation's next generation. If the rights of the children of the perpetrators of crime can be properly protected and guarded, then it can change their future for the better. All actions taken by the government against the children of criminals still refer to the applicable rules, if the cases of children can still be resolved by way of deliberation or consensus, then the diversion should be carried out, so that the government's objective in protecting the rights of children as criminals can be protected.

\section{References}

\section{Journals:}

[1] Akhmad Khisni, and Ragil Tri Wibowo. Restorative Justice in Application for Crime Investigation on Property, Jurnal Daulat Hukum Volume 1 No. 2 June 2018 ISSN: 2614-560X, Unissula.

[2] Ananda, Fiska. Penerapan Diversi Sebagai Upaya Perlindungan Hukum Terhadap Anak Pelaku Tindak Pidana, Jurnal Daulat Hukum Vol. 1. No. 1 March 2018 ISSN: 2614-560X, Unissula.

[3] Maryanto, and Hadi Noor Cahyo. Implementation of The Settlement of The Case Restorative Justice In Fights By Children Because The Effect Of Liquor (Case Study In The Polres Kudus), Jurnal Daulat Hukum Volume 2 Issue 1, March 2019 ISSN: 2614-560X, Unissula.

[4] Sri Kusriyah, and Rizky Adiyanzah Wicaksono. Implementation Of Restorative Justice Approach In Legal Protection Against Lightweight Crime By The Children, Jurnal Daulat Hukum Volume 1 Issue 4 December 2018 ISSN: 2614560X, Unissula.

[5] Umar Ma'ruf and Anita Indah Setyaningrum. Diversi Sebagai Bentuk Penyelesaian Perkara Pidana Anak Melalui Pendekatan Restorative Justice Oleh Penyidik Polda Jawa Tengah, Jurnal Hukum Khaira Ummah Vol. 12. No. 4 December 2017, Unissula. 
[6] Umar Ma'ruf, and Yudi Hendarto. Diversion In Children Criminal Justice System Through Restorative Justice, Jurnal Daulat Hukum Volume 1 Issue 2, June 2018 ISSN: 2614-560X, Unissula.

\section{Books:}

[1] Adang, and Yesmil Anwar. (2009). Sistem Peradilan Pidana Konsep Komponen Dan Pelaksanaannya Dalam Penegakan Hukum Di Indonesia. Bandung: Widya Padjadjaran.

[2] Waluyo, Bambang. (2004). Pidana Dan Pemidanaan. Jakarta: Sinar Grafika.

\section{Internet:}

[1] https://knowledgeisfreee.blogspot.com/2015/10/pengertian-penegakanhukum-kedasaran.html, downloaded on November 26, 2020 at 12:33 WIB. 